\title{
Seismic devices for bridges
}

\author{
D. Mestrovic \& G. Grebenar \\ Faculty of Civil Engineering, University of Zagreb, Croatia
}

\begin{abstract}
The paper summarizes earthquake calculation in accordance with Eurocode 8, ACI regulations and codes applied in Croatia (Europe). Basic data about earthquakes are given and an overview of seismic devices is presented. Calculations for Zeceve Drage (Croatia) bridge are made. Time history analysis was calculated for accelograms based on earthquakes occurring in Petrovac (1979), with magnitude of 6.8, and in Ulcinj (1979), with magnitude 5.3, (former Yugoslavia). New methods of structure protection with dampers were applied on the bridge. Spectrum analysis based on EC $8 / 2$ for ground acceleration of $0.19 \mathrm{~g}$ for the past period of 500 years, and time history analysis for ground acceleration of $0.25 \mathrm{~g}$ and for the past period of 1000 years was used. The damper effect on a bridge with two spans was tested in a laboratory of Civil Engineering Faculty of Zagreb University, Croatia.

Keywords: seismic devices, damper, elastomer bearing.
\end{abstract}

\section{Introduction}

When designing structures in seismically active regions, it is essential to know characteristics of ground motion. Regulations usually determine maximum effective ground acceleration. The earthquake ground shaking is usually presented in the form of a response spectrum of acceleration. That acceleration is actually an attempt to describe potentially destructive ground motion. Generally, acceleration tends to be equal with actual maximum ground acceleration resulting from an earthquake.

Site conditions of soil, such as its type and load bearing capacity, are also important. If short periods prevail, structure is rigid and founded on rocky soil, then such structure has small natural periods and earthquake would have catastrophic effects on this kind of structure. And if a structure is slender and founded on soft ground and subjected to earthquake with predominant longer 
periods, the earthquake effects on the structure could be catastrophic. The earthquake effect in a particular region is determined by its intensity and strength. Earthquake is phenomenon of energy. To avoid damage leading to collapse of a structure, dissipation of energy should be as high as possible. This is achieved by ductility of particular elements of the structure, and recently, by modern devices.

\section{Modern seismic devices}

Earthquake effect on the structure represents action of inertion forces caused by ground motion. How great these forces will be depends on seismic excitation and natural periods of the structure. The force value can be limited by softening of structure, while a degree of damage is lowered by stiffening the structure. Since these two requirements are contradictory, the use of anti-seismic devices has increased, because their application ensures elastic behavior of structural elements. Although the new methods of structure protection were proposed almost a century ago, until today only a small number of examples were applied in practice. This can be explained, firstly, by difficulty in adapting the existing seismic regulations to actual execution of seismically resistant structures, and secondly, by shortage of appropriate devices which would enable safe and effective construction of seismically protective systems. Dimensioning of structure in case of earthquake refers to stiffening or softening. Stiffening can be permanent or temporary. Permanent stiffening is achieved by greater dimensions of a structure, and temporary stiffening by shock transmitters. Softening is achieved by isolating a structure and by dissipation of energy (T and Y strategy). T-strategy represents increase of natural periods, and $Y$ strategy limits the forces transmitted between superstructure and piers. T-strategy is achieved by elastomers, as well as by highly dampening elastomers, and Y-strategy, by hysteresis or hydraulic dampers. Dissipating isolators combine the above. Bridges can be protected from earthquake by selection of proper equipment. Most significant pieces of equipment are: fixators, base isolators, isolators with dissipating effect, friction pendulum, seismic slide isolators, bearings with frequency converters, shock transmitters, dampers: hydraulic, hysteresis and dampers with tuned mass, and expansion joints. Fixators are foreseen to transmit a given force without displacement. They are known as fixed bearings. By contrast, elastomers enable floating support for superstructure, and are also called base isolators. The base isolators increase natural period of a structure, which result in reduction of acceleration during seismic attack. They have effect of a spring which makes a structure to return into its original position. Dissipating effect of isolators is achieved when elastomer is furnished with lead core which dissipates energy. Following types of bearings are developed especially for earthquake: friction pendulum, seismic slide isolator and bearing with frequency converters. Friction pendulum consists of bearing slab with sphere and one slide cladding made of polished stainless steel. Seismic steel slide isolator transmits vertical loading and ensures free horizontal flexibility. It has recentering capacity, and can have high dampening properties. Departure from 
resonant area is achieved by bearings with frequency converters. Shock transmitters are important for transmission of horizontal force. They are hydraulic devices which decrease quick movement of superstructure as compared to substructure, which result in previously foreseen force. Shock transmitters produce temporary connections which become active only during dynamic excitations. Dissipation of energy is produced by dampers. The most important types are: hydraulic, steel and dampers with tuned mass. Figure 1 represents force-displacement relation for typical shock transmitter.

Viscous dampers are devices that enable displacements due to temperature changes, creep and shrinking, but do not create considerable forces, however, they dissipate great quantities of energy during sudden dynamic entrance of seismic energy, and that energy is transformed to heat. Steel hysteresis damper dissipates energy using property of steel fluctuation. Damper with tuned mass is installed at the structure point that has significant or highest vibration level. The device consists of moving/swinging mass, spring and damping element. Advantage of the device is that it shifts structure frequency from resonant area. Very important are expansion joints. They are designed in such a way to take seismic displacements, in addition to service displacements.

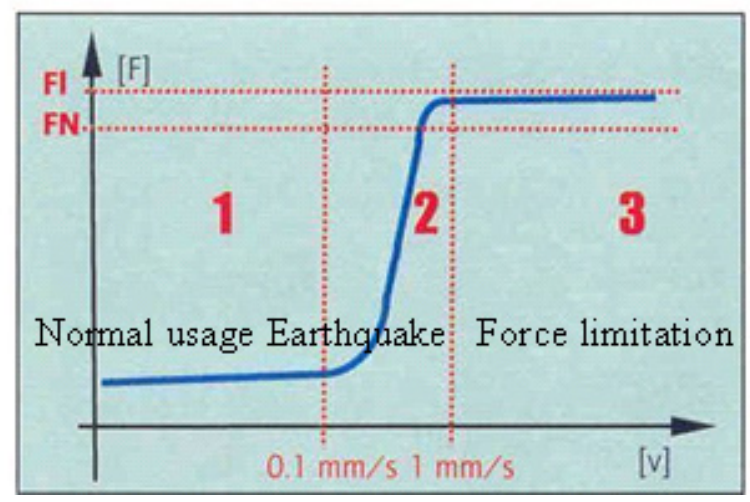

Figure 1: Force-displacement relation for shock transmitters.

\section{Regulations}

Majority of regulations take into account the following: seismicity factor, dynamic factor, factor dependent on soil category, factors of damping, structure, risk, and importance of a structure. The earthquake effect is described by effective maximum ground acceleration. 
Table 1: $\quad$ Q factor.

\begin{tabular}{|l|l|l|}
\hline \multirow{2}{*}{ Ductile member } & \multicolumn{2}{|l|}{ Post-elastic behavior } \\
\cline { 2 - 3 } & $\begin{array}{l}\text { Limited } \\
\text { ductile }\end{array}$ & Ductile \\
\hline Reinforced concrete columns & & \\
\hline Vertical columns - bending & 1.5 & 3.5 \\
\hline Bent column - bending & 1.2 & 2.0 \\
\hline Short strong column & 1.0 & 1.0 \\
\hline Steel columns & & \\
\hline Vertical column - bending & 1.5 & 3.0 \\
\hline Bent column - bending & 1.2 & 2.0 \\
\hline Natural support - column & 1.5 & 2.5 \\
\hline Eccentric support - column & - & 3.5 \\
\hline Abutments & 1.0 & 1.0 \\
\hline Arches & 1.2 & 2.0 \\
\hline
\end{tabular}

Table 2: $\quad$ R factor.

\begin{tabular}{|l|l|}
\hline SUBSTRUCTURE & $\mathrm{R}$ \\
\hline Wall-type pier & 2.0 \\
\hline Reinforced concrete pile bents & \\
\hline a) only vertical piles & 3.0 \\
\hline b) one or more batter piles & 2.0 \\
\hline Single columns & 3.0 \\
\hline Steel or composite steel & \\
\hline and concrete pile bents & \\
\hline a) only vertical piles & 5.0 \\
\hline b) one or more batter piles & 3.0 \\
\hline Multiple column bents & 5.0 \\
\hline CONNECTIONS & 1.2 \\
\hline Superstructure to abutment & 0.8 \\
\hline $\begin{array}{l}\text { Expansion joints within a } \\
\text { superstructure span }\end{array}$ & 0.8 \\
\hline
\end{tabular}

In order to avoid explicit non-linear analysis, and taking into account capacity of a structure to dissipate energy through ductile behavior of its members, and also by other mechanisms, a linear analysis is applied based on a response spectrum which is reduced as compared to the elastic spectrum. Because of that the reduced spectrum is called design spectrum. Design response spectrum is obtained from elastic by means of behavior factor "q". Behavior factor " $q$ " is approximation of value of the seismic forces which would affect a structure, if its response is completely elastic, with $5 \%$ of relative viscose damping, and of 
minimum seismic forces that can be used for designing with conventional linear model and which would at the same time ensure a satisfactory response of a structure. Value for "q" is given in a table 1. Values given in the table can be applied only to accessible plastic hinges. When a superstructure leans against columns of various degrees of stiffness, then a lowest " $q$ " value is selected for calculation purpose, while $\mathrm{q}=1.0$ is used for calculations of columns with elastomers. Seismic forces for given columns and connections are determined by dividing elastic forces by appropriate Modification Factor (R). Values for R are given in the table 2. For EC8/2 it should be noted that structure ductility is described by behavior factor "q", and for ACI regulations modification factor R is used. Regulations valid in Croatia do not explicitly require checking of ductility, property essential for dissipation of seismic energy, which increases a risk of load bearing capacity and applicability of reinforced structures calculated according to such regulations.

\section{The bridge Zeceve Drage}

Zeceve Drage bridge is $940,8 \mathrm{~m}$ long. It is situated in a horizontal curve. The height difference between left and right abutment is approximately $23 \mathrm{~m}$. Span structure is a box girder $12,5 \mathrm{~m}$ wide and $4 \mathrm{~m}$ high. The area of cross section above the support is $10,2 \mathrm{~m}^{2}$, and in the field it is $9,4 \mathrm{~m}^{2}$. The piers have rectangular cross section at the top, which changes into hollow, with $30 \mathrm{~cm}$ thick wall, expanding to $50 \mathrm{~cm}$ at the bottom. The bridge has 18 piers, the highest being approx. $53 \mathrm{~m}$ high. The spans are $50 \mathrm{~m}$, except for the ones closer to the abutment, which are $40 \mathrm{~m}$. Span structure was modeled using shell elements, piers are modeled as beams. Supports are modeled using spring elements. Connection pier-span structure was modeled with coupling elements. Material for span structure was concrete C45, piers are C35 and structural steel is S400 (according to Eurocode 2 regulations). All loads applied on bridge for purpose of seismic calculations are used according to Eurocode 8 regulations.

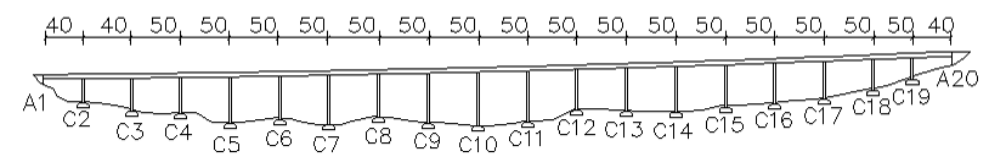

Figure 2: $\quad$ Longitudinal section of the bridge.

\section{Results of analysis}

Two analyses were used for earthquake calculation - spectrum analysis based on EC8/2 for ground acceleration of $0,19 \mathrm{~g}$ for the past period of 500 years, and time history analysis for ground acceleration of $0,25 \mathrm{~g}$ and for the past period of 
1000 years. Spectral analysis was conducted for elastic and design spectrum, with $\mathrm{q}=1,5$ (limited ductile behavior). Time history analysis was calculated for accelograms of magnitudes 5.5, 6, 6.5 and 7, with distances of 0 and $15 \mathrm{~km}$ from epicenter, based on earthquakes occurring in Petrovac, in April 1979, with magnitude of 6.8, and Ulcinj, in April 1979, with magnitude 5.3, in the region of former Yugoslavia. Thirty (30) modes were used for calculations. The hydraulic viscous dampers of 1500,2000 and $3000 \mathrm{kN}$ were added in longitudinal direction connecting the abutments. The dampers of $2000 \mathrm{kN}$ were selected because they enable elastic behavior of the piers. The table 3 represent results of forces in cross section at the piers bottom.

Table 3: Calculation results (shear forces in $\mathrm{kN}$ ) of Zeceve Drage bridge columns S8 to S10.

\begin{tabular}{|l|l|l|l|}
\hline Column & S8 & S9 & S10 \\
\hline $\begin{array}{l}\text { Elastic } \\
\text { spectrum }\end{array}$ & 4354 & 5597 & 2567 \\
\hline $\begin{array}{l}\text { Design } \\
\text { spectrum }\end{array}$ & 2885 & 3709 & 1701 \\
\hline $5.5 \mathrm{M} \mathrm{0} \mathrm{km}$ & 231 & 298 & 141 \\
\hline $5.5 \mathrm{M} 15 \mathrm{~km}$ & 313 & 402 & 184 \\
\hline $6.0 \mathrm{M} 0 \mathrm{~km}$ & 460 & 592 & 276 \\
\hline $6.0 \mathrm{M} 15 \mathrm{~km}$ & 350 & 450 & 210 \\
\hline $6.5 \mathrm{M} 0 \mathrm{~km}$ & 442 & 567 & 264 \\
\hline $6.5 \mathrm{M} 15 \mathrm{~km}$ & 546 & 704 & 331 \\
\hline $7.0 \mathrm{M} 0 \mathrm{~km}$ & 1507 & 1936 & 889 \\
\hline $7.0 \mathrm{M} 15 \mathrm{~km}$ & 1005 & 1292 & 582 \\
\hline $\begin{array}{l}\text { DAMPER } \\
1500 \mathrm{kN} \\
7.0 \mathrm{M} 0 \mathrm{~km}\end{array}$ & 843 & 1081 & 452 \\
\hline $\begin{array}{l}\text { DAMPER } \\
\begin{array}{l}\text { 2000 kN } \\
7.0 \mathrm{M} 0 \mathrm{~km}\end{array}\end{array}$ & 657 & 840 & 356 \\
\hline $\begin{array}{l}\text { DAMPER } \\
\text { 3000 kN } \\
7.0 \mathrm{M} 0 \mathrm{~km}\end{array}$ & 467 & 594 & 283 \\
\hline
\end{tabular}

\section{Laboratory testing}

In laboratory the damper effect on a bridge with two spans and elastomer bearings was tested, and the results were compared with data obtained by calculations. For bridge with damper in longitudinal direction, the experiments confirmed results obtained by calculations. 


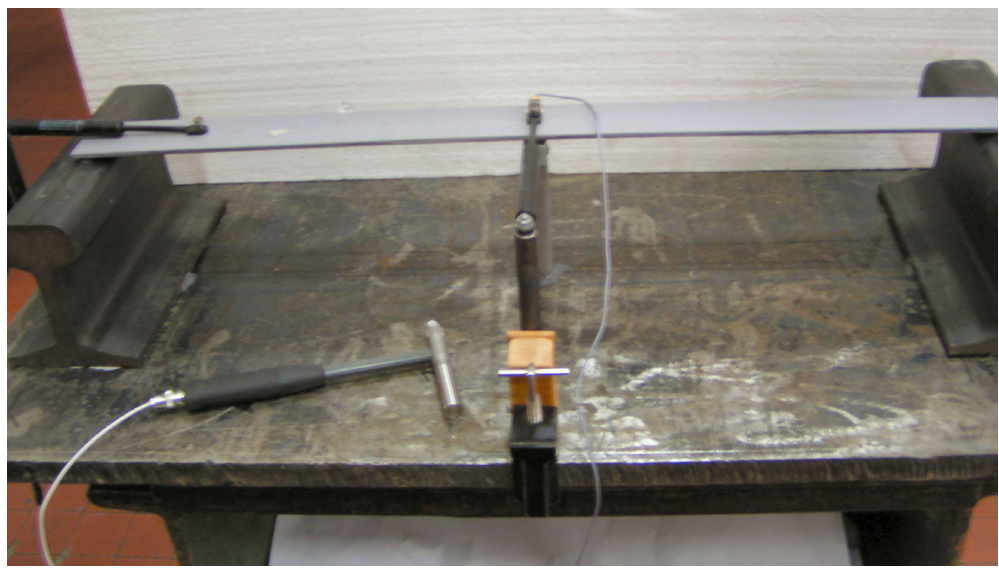

Figure 3: $\quad$ Model of bridge with dampers.

Table 4: $\quad$ Frequencies and periods (results of experiments and calculations).

\begin{tabular}{|l|l|l|l|l|}
\hline & \multicolumn{2}{|l|}{$\begin{array}{l}\text { Structure without } \\
\text { damper }\end{array}$} & \multicolumn{2}{l|}{$\begin{array}{l}\text { Structure with damper } \\
(50 \mathrm{~N})\end{array}$} \\
\hline axis & \multicolumn{2}{|l|}{ Frequency $(\mathrm{Hz})$} & \multicolumn{2}{l|}{ Frequency $(\mathrm{Hz})$} \\
\hline & computed & experiment & computed & experiment \\
\hline $\mathrm{x}$ & 105.39 & 99 & 122.48 & 118 \\
\hline $\mathrm{y}$ & 107.96 & 99 & 121.32 & 127 \\
\hline
\end{tabular}

Table 5: $\quad$ Damping of bridge model.

\begin{tabular}{|c|c|c|}
\hline Axis & Without damper & $\begin{array}{c}\text { With damper } \\
(50 \mathrm{~N})\end{array}$ \\
\hline $\mathrm{x}$ & $9.8 \%$ & $14.89 \%$ \\
\hline $\mathrm{y}$ & $10.6 \%$ & $12.47 \%$ \\
\hline
\end{tabular}

\section{Conclusion}

Selection of adequate equipment is necessary for the bridge protection. Today, dampers are being used very often. They reduce the seismic forces, increase damping of structure and enable uniform distribution of induced energy over the entire structure. This paper focuses on their greatest importance, reduction of the forces in piers by damping, during which they remain in elastic state. The bridge piers have elastic behavior, so that no significant structure damages occur during earthquake. 


\section{References}

[1] Chopra, A. K., Dynamics of Structures, Theory and Applications to Earthquake Engineering. New Jersey: Prentice Hall, 1995.

[2] Clough, R.W., and Penzien, Dynamics of Structures, New York: McGraw Hill, 1993.

[3] Petersen, C., Schwingungsdaempfer im Ingenieurbau, Muenchen: Maurer Soehne GmbH \& Co. KG, 2001.

[4] Nizic, A., Seismic devices in bearing structures, M.Sc. Degree thesis, 2004

[5] D. Cizmar, A. Nizic, D. Mestrovic, "Importance of dynamic characteristics of accelograms to structural response", SECED Conference, 2005.

[6] A. Mihanovic, "Dynamics of structures", University of Split - Faculty of Civil Engineering, 1995.

[7] SeismoSoft [2004] "SeismoSignal - A computer program for signal processing of strong-motion data" [online]. Available from URL: http://www.seismosoft.com.

[8] S.R.A.C. inc., "COSMOS/M 2.6 Electronic Documentation", ASTAR Advanced Dynamics, p. 166-175, Los Angeles, 2000.

[9] C. I. Huerta Lopez, Y. Shin, E. J. Powers, J. M. Roesset, "Time frequency analysis of earthquake records", 12WCE2000, 2000. 